\title{
Independence Habituation of Autism Students in the Learning Management
}

\author{
Nanik Wilujeng, Tin Agustina Karnawati, Moh Bukhori \\ Graduate Program of Management, Institut Teknologi \& Bisnis Asia Malang \\ Email: jengwilujeng27775@gmail.com
}

\begin{abstract}
This research aims to examine the independence habituation for students with autism in learning management at SMK (vocational high school) Tunas Bangsa, Malang. It covers the planning, implementation, and evaluation of the independence habituation in the learning process for students with autism. Besides, it studies the problems and solutions made during the application of the learning program. It is qualitative research with autistic students of grade XII as the subject. The informants of this research involved the headmaster; normative, adaptive, and productive teachers; the advisor of exceptional teachers; parents; and psychologists. The data collection methods include observation, interview, and documentation. The results of the study cover the planning, outcome, and learning implementation through the independence habituation of students with autism at SMK Tunas Bangsa, Malang. The learning independence appears from the development of the students' independence. The problems found during the independence habituation process on the learning process are solved through some solutions applied by all of the educational elements of the comprehensive learning management at SMK Tunas Bangsa, Malang.
\end{abstract}

Keywords: Autism, Habituation, Independence, Learning Management

\section{INTRODUCTION}

Since 2012, SMK Tunas Bangsa Malang has implemented an education program for students with exceptional needs (inclusive education), in which they study together with other students in a formal education program. The students are categorized as students with special needs, such as autism. (Wei et al., 2014). Children with autism represent those who tend to be silent and alone (Chaplin, 2011). Autism grows due to interference that happens because of specific abnormalities of nerve cause abnormal brain function, which disturbs their growth, communication, and social interaction skill (Sunu, 2012). Consequently, children with autism become dependent on others (Guiraud et al., 2011; Schriber et al., 2014).

Children with autism have limited abilities, as explained in Minister of Education Regulation No 70 the Year 2009. That regulation mentions that children with exceptional needs are students with disabilities, including blind, deaf, speech impaired, mentally disabled, physically disabled, imbalance, having learning difficulty, slow to learn, disability in motoric system, being a victim of narcotics and having other disabilities/dual-disability.

The professor of psychology education, Universitas Indonesia, Mangunsong (2009) states that children with special needs are those who need to obtain special training and services to maximize their human function entirely because of their 
physical or mental difference compared to other children. The difference includ es mental features, sensory ability, physic and neuromuscular, social, and emotional behavior, communication ability, or a combination of the two or more. This condition refers to the self-adaptation ability to the environment where they grow up. One of these is inclusive education.

Minister of Education Regulation No. 70 of 2009, defines inclusive education as an operating system in education. This system enables students with special needs who have the potential talent and interest to attend learning in the education area together with the other students. Inclusive education aims to give an ample opportunity to all children with special needs. It also functions as one of the implementations of education that respect the differences, variety, and humanism to all students with a physical, emotional, mental, and social disability. They have potential intelligence or exceptional talent to receive a good education based on their need and ability (Wibowo \& Muin, 2018).

Through the implementation of independent character education, students are taught about their daily activities and regular situation, for example, proper mealtime. In this situation, they learn not only the way to eat but also the source, quality, taste, and color of food. Later, they can relate this experience to their previous one such as another place and person. Their experiences can be associated and developed into a new concept by the students as an "incomplete material" for cognitive development in the future. Every parent expects their children to be independent in doing their daily activities such as cooking, mopping and sweeping the floor, shopping, washing, ironing, typing, cleaning the bedroom, and so on (Handojo, 2003). Several autism students have excellent academic competence and possibly have the ability to apply those skills to live independently (Anderson et al., 2016; Gurbuz et al., 2019). The independence habituation can be applicable to autism children repetitively and continuously. Later, it can be their habit and transform the autistic children to be independent in the future.

Fajrin (2015) concludes that being independent is someone's effort to survive by avoiding problems with other people, an initiative on doing something, and a believe apart from any influence from the surroundings, and not being dependent on the others. The independent features are: being capable of determining their own life, being capable of taking care of themselves, being responsible, being creative and initiative, and being capable of making decisions and resolving personal problems. In the context of children with special needs, they are given lessons about independence habituation through guidance or exercises, since there are two aspects of background. Those aspects are independent and related to the maturity of social culture.

In all education process at school, learning is the primary activity. In other words, the successful accomplishment of education depends on excellent learning processes (Darling-Hammond et al., 2009). Proper learning management consists of four phases, such as planning, implementation, assessment, and control or supervision. Learning management, according to Rohman and Amri (2012), is an effort to reach the learning objectives through activities that accelerate talent and interest, focus, happiness, background with expanded field activity aiming to develop their lifestyles in the future. Learning management is a fundamental 
application, concept, and theory management in a learning activity to reach learning goals (Saryanto, 2006).

In inclusive education, there is an individual learning program (PPI) to build and develop a lesson plan for children with exceptional needs (Khoeriah, 2017). Mercer et al. (1989) state that an independent program refers to a learning program where students complete their tasks under a certain period suitable to the condition and motivation. PPI refers to the style and power that students need in the learning process (Lync, 1994). According to Smith and Lucasson (1995), there are several components in individual learning program including (a) children standard ability coverage on academic ability, intelligence levels, health, psychological condition, and disability characteristic; (b) the general goal and the explanation of specific purpose suitable for students' needs such as their levels; (c) availability of the particular service to the children; (d) broader children service following regular program; (e) projection when the application starts; (f) duration used for the services; and (g) evaluation procedure. Additionally, individual learning subsists of three activities, namely presentation, controlled practice, and independent practice (Mercer et al., 1989).

Based on the above explanation, the researcher aims to examine the independence habituation for students with autism in the learning management at SMK Tunas Bangsa Malang. It covers planning, realization, and evaluation availability on the learning process for students with autism. Besides, it investigates the obstacle and solution revealed in the learning program applications.

\section{METHODS}

This research employs qualitative methods with field studies. It focuses on one unit analysis of independence habituation applied to students with autism in the learning management at SMK Tunas Bangsa Malang. The school is categorized as inclusive school based on Malang's Major Regulations No. 188.45/342/35.73.112/2012 and Governor Regulation of East Java Educational Province No. 188.4/1083/101.4/2019 about the legalization of private inclusive education of senior high schools (SMA) and vocational high schools (SMK), academic year 2019/2020.

This research used primary and secondary data sources. The primary data were collected from an exclusive in-depth interview with a list of questions and passive participation observation of the headmaster (KS), coordinator advisor of special teachers, four subject teachers, two parents (OS), and psychologist (PSI) at SMK Tunas Bangsa Malang. Contrarily, the secondary data were collected from school documentation, such as photos, articles, and studies related to this research. The data collection was completed based on purposive sampling, involving the headmaster, psychologist, four subject teachers, one coordinator of special teachers, and two parents.

The collected data were analyzed qualitatively using Miles and Huberman models. The data validity was tested using four methods, namely credibility, transferability, dependability, and conformability tests. 


\section{RESULTS \& DISCUSSION}

Learning management is one of the abilities that should be possessed by the teacher in the process of transferring materials to students, primarily the disabled and autistic students in particular. Therefore, the role of a teacher is significantly essential to conduct the learning program successfully. Teachers are obliged to do two primary tasks, conducting the teaching activities and managing the class so that the learning process can be completed effectively and efficiently. It is expected that the research can show the learning process of students. It aims to examine the students' independence habituation on learning management at SMK Tunas Bangsa Malang, which covers the process of planning, implementation, and evaluation. Besides, it also discusses the obstacles and solutions found during the learning program application.

Novita (2017) states that learning management in the ongoing process should be in compliance with the existing regulation, such as lesson planning management, to identify and monitor the children's growth. During the observation, the psychologist applied the management method based on the modified curriculum. On the other hand, the implementation of management learning detects the growth of children through observation. However, the evaluation of learning management is conducted once a month by the teacher and parents. Meanwhile, every three months, another evaluation is carried out by a psychologist with parents.

Furthermore, an in-depth-interview was performed by the researcher to the informant, observation participant, along with documentation related to the independence habituation for students with autism in learning management at SMK Tunas Bangsa, Malang. The result shows that students with autism and special needs enrolled as autism students at SMK Tunas Bangsa, Malang have different limitations or disabilities, as presented in Table 1.

Table 1. The number of students with Autism and Special Needs

\begin{tabular}{ccccc}
\hline No & Sex & Autism & Slow Learners & Total \\
\hline 1 & Male & 2 students & 7 students & 9 students \\
2 & Female & 1 student & 2 students & 3 students \\
& Total & 3 students & 9 students & 12 students \\
\hline
\end{tabular}

The table shows the total special needs and autistic students, both males and females, in the academic year of 2019/2020 are 12 students. Among those students, three students require inclusive education services. Inclusive education treatment is intended to be given to the special needs students with different indications such as academic, behavior, independence, speaking therapy, less concentration, and so forth. This is implemented based on the ability, talent, and interest of the students according to individual learning programs covered in one student one program.

The finding of the research on learning management and implementation of character independence education of autism students at SMK Tunas Bangsa Malang are illustrated in Figure 1. 


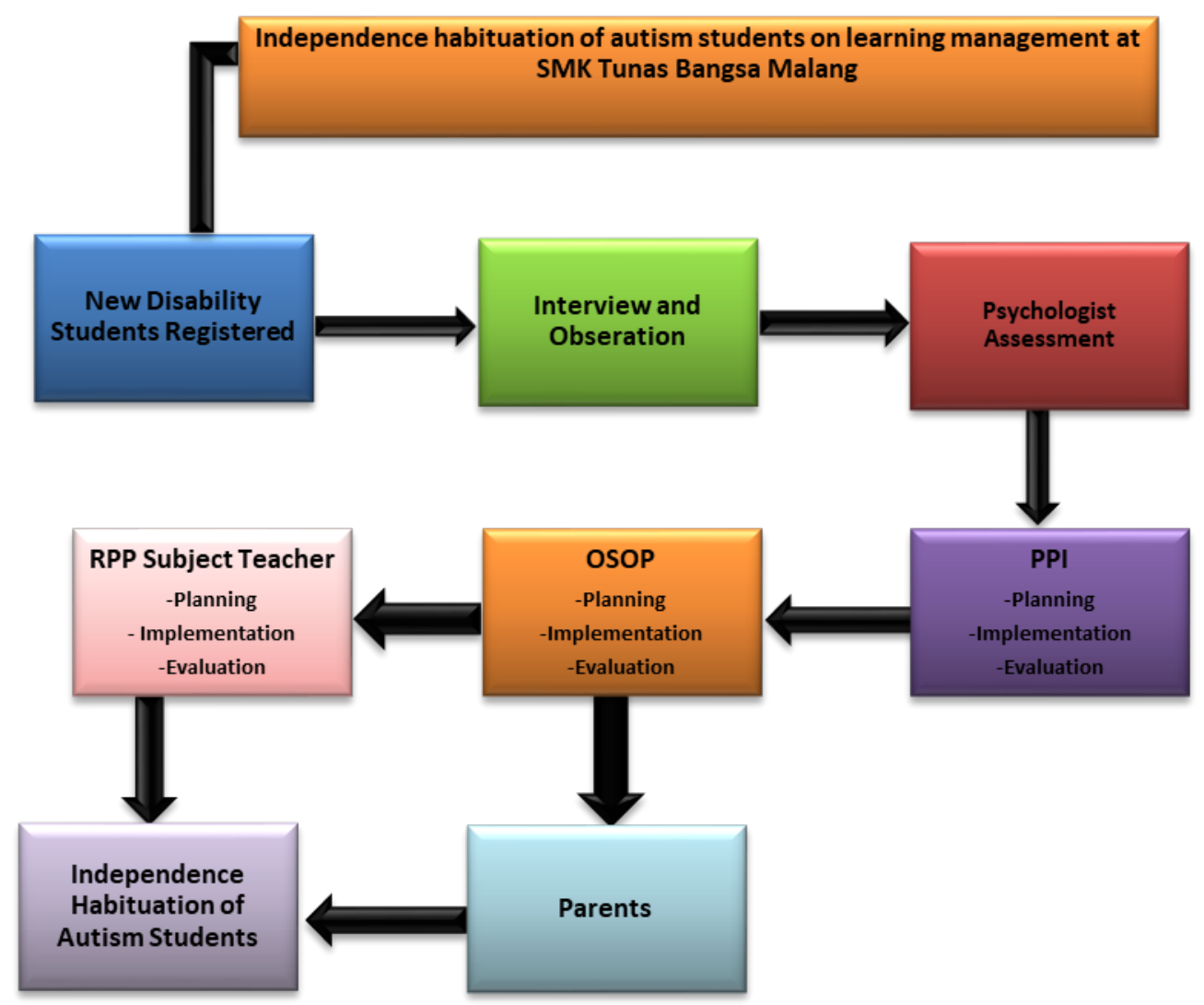

Figure 1. Independence Habituation of Autism Students on the Learning Management Structure

Figure 1 displays learning management at SMK Tunas Bangsa Malang, since the students are registered as students with special needs. After the enrollment, the new students are sorted. The students with special needs require observation from school; therefore, an interview is conducted to the students and their parents. After that, the school invites the psychologist to perform psychology assessments to new students with exceptional needs to identify their category. The results of psychological assessment later are given to the advisor of the special teacher to be used as the standard to make individual learning programs in SMK Tunas Bangsa, called OSOP or One Student One Program. OSOP also becomes the standard of the subject teacher to create a lesson plan and implement it, primarily for students with special needs in collaboration with special teacher advisors. OSOP, as an individual learning program, is also applied by parents of special needs students at home as the continuation of the program implemented in school. OSOP is a program designed to be used by all learning elements such as teachers, students, and parents, which includes habitual or independent habituation for students with autism. The OSOP application results in students' independence, including those with special needs and students with autism. Gilic (2017) research result explains the effectiveness of this kind of program (such as OSOP) can give effective results to build interaction between teachers at school, students with and parents at home. The purpose is to increase students with autism academic activity. 
According to the observation result conducted at SMK Tunas Bangsa Malang, the assistance given by the school to the students with special needs is considered sufficient from academic and non-academic services. Yet, the assistance is still not optimal. The teaching process in class is generally the same. The teacher gives the same material for students with special needs and regular students. At first, the teacher explains the material to students before giving a question and answer session. The teacher gives more attention to the students with special needs, trough more intense communication with the students. The seats of students with special needs are also located closer to the teacher; therefore, it eases the teacher to give attention to them. Results of the evaluation conducted at school reveal that the attention given by teachers is still the same between students with special needs and the regular ones. Students finish the task calmly without any special treatment, and the question task for students with special needs and regular students are the same. Meindl et al. (2012) mention that this kind of class composition can bring the benefit not only to students with autism, but also the regular students, who can understand the real differences.

The facilities at SMK Tunas Bangsa Malang, in general, is quite complete since it is classified as an inclusive school. It is shown by the inclusive special rooms that subsist of a theory room, teaching room, and life-skill corner. However, the textbooks and instrument models used in the teaching process are the same. There is no particular book, but the teaching method used in the teaching process is different. Additionally, SMK Tunas Bangsa Malang already has life-skill development activities for students with special needs. The non-academic activities given by the school include cooking and extracurricular activities. The extracurricular activities are attended by all the students, including the students with special needs and regular students. The extracurricular activities at SMK Tunas Bangsa Malang consist of scouting clubs, soccer clubs, along with talent clubs such as multimedia, makeup, writing, reciting Al-Quran, as well as the English language.

\section{Independence Habituation for Students with Autism in the Learning Plan Management at SMK Tunas Bangsa Malang}

The curriculum used at SMK Tunas Bangsa Malang is modified by their special advisor teacher and adapted based on the students' mental age, different from their physical age. Besides, the curriculum is also modified based on the assessment results from the psychologist. The following are the results of the researcher observation and documentation based on independence habituation to autism students on learning planning management at SMK Tunas Bangsa.

The curriculum is modified following the syllabus and the implementation of the lesson plan. The learning model uses in the regular class is Pull Out, which combines regular students and students with special needs in a single class. In one condition, the students with special needs can be 'pulled out' from the regular class and learn together with a special advisor teacher in the special classroom. Curriculum modification covers modification based on the content/material curriculum, teaching process, class management, time allocation, facilities, and learning environment.

The lesson plan is established by the teachers and advisor of the special needs students, covering the methods applied, materials to deliver, and the media used by 
the teachers during the teaching process. The teacher designs a learning program involving special teacher advisors, parents, and psychologists. Even though the teachers at school are not from a special education background, they are actively involved in the learning process for students with autism at school (Kurniawati et al. 2012).

The materials or learning methods delivered by the teachers to every autistic student are different based on each of their abilities. If the students do not respond to the instruction, they are directed to stay focus on the tasks they should finish. If the class teachers and subject teachers find an issue, they collaborate with the advisor to find a solution. Independence habituation task settlement is in the form of material delivered in the class that is repeated until the students with disabilities or autism are consistent and independent.

\section{Independence habituation for Students with Autism in the Learning Application Management at SMK Tunas Bangsa, Malang}

Learning implementation at SMK Tunas Bangsa Malang already shows the learning process respected distinctively by every individual. The methods used by the teachers in the teaching process between one student to others, such as autism students to others and hyperactive students to other hyperactive students. The observation results show that the teachers have already planned the learning process, such as making different programs for the various students. They use detection teens' growth standards, in general, to strengthen the students by giving assistance and encouraging them to be more active. The teacher has already used learning media to deliver the material and the methods adopted for students' abilities. In general, teachers also develop interaction with autistic students to create a more accessible learning activity (Runcharoen, 2014).

The results of the research observation and documentation on the independence habituation of students with autism in the implementation of learning management at SMK Tunas Bangsa are explained. First, the learning process given to each student is different based on their mental age, which is different from their physical or development levels. The example of the provided learning process is communication through verbal and non-verbal, giving a task or instruction trough directed and modeling. The teacher will be more active in the learning process to stimulate the students, and they can give a response to what the teacher did. Second, at SMK Tunas Bangsa, the learning program used is based on the individual learning program composed by the exclusive advisor according to the assessment result from the psychologist. A program named OSOP is formulated. It means that the students learning process will be different from one another based on their talent, interest, and ability. Third, parents are involved in the independence habituation implementation for students' programs by monitoring them in finishing their homework. Gilic (2017) explains that in the case of autism in the regular class, students have a bigger challenge in doing homework; thus, parents' help, as a structured program, should be well maintained. 


\section{Independence Habituation of Students with Autism in Learning Evaluation Management at SMK Tunas Bangsa Malang}

The evaluation and assessment process at SMK Tunas Bangsa Malang is performed by the special teachers in collaboration with their advisor. The evaluation standard is based on the students' abilities. The result of the research on the independence habituation to autism students in the learning evaluation management at SMK Tunas Bangsa Malang is presented. First, an evaluation is done by examining the programs while the student's observation is performed to the students. The evaluation process is done every three months by the subject teachers, the advisor of the special teachers, and the coordinators of special advisor teachers. The evaluation of the result of the final assessment is the full responsibility of the coordinator of the special teachers. It is conducted by studying the notes and making a direct interaction with the students. Second, if the program does not run effectively, the teachers can change it with the new one. If the program is considered effective, it is repeated in the following months until the program succeeded. Third, the assessment standard between students with special needs and autistic students is different. Besides, the assessment depends on the students' ability and knowledge. Other than that, other aspects, such as attitude and attendance, are also evaluated. Fourth, the observation results and parents' statements show that the students' development and independence develop well according to the students' independence indicator. Lastly, the evaluation of the learning implementation at SMK Tunas Bangsa Malang is relevant to the research conducted by Asrul et al. (2014) that reveal assessment on learning is provided due to the learning process. Assessment is a decision-making process on the quality of the students' learning outcomes. It aims to identify the attainment of the learning objectives of the students.

\section{Problems and Solution}

During the implementation of independence, habituation, and learning management on students with autism, there are problems and solutions. The interview with some informants, such as the headmaster, teachers, and parents, reveals the following solutions : (1) Making a campaign for socialization to the society about the existence of SMK Tunas Bangsa Malang as an inclusive institution; (2) Making MoU with all of the elements from SMK Tunas Bangsa: teachers, students, GPK and regular students' parents about the inclusive education institution at SMK Tunas Bangsa Malang; (3) When the students show the symptoms of a tantrum in the class, the subject teachers will collaborate with the advisor of the special teacher to handle the students; (4) If the students want to do the task, the first thing that the teacher should do is to direct and to motivate the students to finish the task; (5) Coordination between teachers and parents is maintained through the report and social media groups related to the students' activities at school.

\section{CONCLUSION}

Independence habituation for autism students in the learning plan management at SMK Tunas Bangsa Malang is established by modifying the curriculum in compliance 
with the condition of the autistic students. The regular class applies the 'Pull out' learning model, differently made between one student with another. The program is called One Student One Program (OSOP). Independence habituation for autism students in the learning implementation management at SMK Tunas Bangsa Malang is applied by class management, Learning plan, and learning evaluation. Independence habituation for students with autism on learning evaluation management is completed by a description assessment system, along with the assessment conducted every three months by the subject teachers, the advisor of special teachers, and parents. The challenge found is successfully handled by doing coordination among the headmaster, teachers, and parents through a book and media social group, in which they regularly discuss the issues or the activity of the students during learning at school. Further research is required to open the opportunity of inclusive education for students with special needs such as autism so that they can be more understood. Furthermore, this system is expected to be better applied in regular schools.

\section{REFERENCES}

Anderson, K. A., McDonald, T. A., Edsall, D., Smith, L. E., \& Taylor, J. L. (2016). Postsecondary expectations of high-school students with autism spectrum disorders. Focus on Autism and Other Developmental Disabilities, 31(1), 1626.

Asrul., Ananda., \& Rosnita. (2014). Evaluasi Pembelajaran. Bandung: Citapustaka Media.

Chaplin, J.P. (2011). Kamus Lengkap Psikologi (Terjemahan Kartini Kartono). Jakarta: PT. Rajagrafindo Persada.

Darling-Hammond, L., Flook, L., Cook-Harvey, C., Barron, B., \& Osher, D. (2020). Implications for educational practice of the science of learning and development. Applied Developmental Science, 24(2), 97-140.

Fajrin, N. (2015). Hubungan antara kemandirian dengan intensi berwirausaha pada mahasiswa Fakultas Psikologi Universitas Islam Negeri Maulana Malik Ibrahim Malang (Unpublished undergraduate's thesis). Universitas Islam Negeri Maulana Malik Ibrahim.

Gilic, L. (2017). Increasing homework completion and accuracy rates with parental participation for young children with autism spectrum disorder. Psychology, Society, \& Education, 8(2), 173-186. https://doi.org/10.25115/psye.v8i2.448

Guiraud, J. A., Kushnerenko, E., Tomalski, P., Davies, K., Ribeiro, H., \& Johnson, M. H. (2011). Differential habituation to repeated sounds in infants at high risk for autism. Neuroreport, 22(16), 845-849.

Gurbuz, E., Hanley, M., \& Riby, D. M. (2019). University students with autism: The social and academic experiences of university in the UK. Journal of Autism and Developmental Disorders, 49(2), 617-631.

Handojo, Y. (2003). Autisme. PT. Bhuana Ilmu Populer Kelompok Gramedia, Jakarta. Khoeriah, D., N. (2017). Individualized educational program dalam implementasi pendidikan inklusif. Inclusive: Journal of Special Education, 3(1), 41-49. 
Kurniawati, F., Minnaert, A., Mangunsong, F., \& Ahmed, W. (2012). Empirical study on primary school teachers' attitudes towards inclusive education in Jakarta, Indonesia.Procedia-Social and Behavioral Sciences, 69, 1430-1436. https://doi.org/10.1016/j.sbspro.2012.12.082

Lynch, J. (1994). Proyection for Children with special need education in asian regio. The World Bank, USA.

Mangunsong, F. (2009). Psikologi dan pendidikan anak berkebutuhan khusus, 1st ed. Lembaga Pengembangan Sarana Pengukuran Dan Pendidikan Psikologi (LPSP3) Kampus Baru UI, Depok, Jakarta.

Meindl, J.N ., Delgado, D., \& Casey, L. B. (2020). Increasing engagement in students with autism in inclusion classrooms. Children and Youth Services Review, 111, 104854. https://doi.org/10.1016/j.childyouth.2020.104854

Mercer, C. D., Mercer, A. R., \& Pullen, P.C. (1989). Teaching Student with learning problems. The United States: Merrill Publishing Co.

Novita, S., (2017). Manajemen Pembelajaran anak berkebutuhan khusus di pusat kegiatan belajar masyarakat teste Belle's Mata Hati Bandar Lampung (Unpublished master's thesis). UIN Raden Intan Lampung.

Permendiknas No. 70 Tahun. (2009). Permendiknas No. 70 tahun 2009.

Rohman, M., \& Amri, S. (2012). Manajemen pendidikan analisis dan solusi terhadap kinerja manajemen kelas dan strategi pengajaran yang efektif. Jakarta: PT. Prestasi Pustakaraya.

Runcharoen, S. (2014). The development of social interaction of children with autism in inclusive classrooms. Procedia - Social and Behavioral Sciences 116, 4108-4113. https://doi.org/10.1016/j.sbspro.2014.01.899

Saryanto. (2006). Peran Kepala Sekolah dalam Manajemen Pembelajaran di SD Negeri Cepogo 01 Kabupaten Boyolali. (Unpublished master's thesis). Universitas Muhammadiyah Surakarta, Surakarta.

Schriber, R. A., Robins, R. W., \& Solomon, M. (2014). Personality and self-insight in individuals with autism spectrum disorder. Journal of Personality and Social Psychology, 106, 112-130. https://doi.org/10.1037/a0034950

Smith, D.D., \& Lucasson, R.,(1995). Special education (2nd Ed.). Allyn And Bacon, Needham Heights.

Sunu, C. (2012). Unlocking autism: panduan memecahkan masalah autism. Yogyakarta: Lintangterbit.

Wei, X., Wagner, M., Christiano, E. R., Shattuck, P., \& Yu, J. W. (2014). Special education services received by students with autism spectrum disorders from preschool through high school. The Journal of special education, 48(3), 167-179. https://doi.org/10.1177/0022466913483576

Wibowo, S. B., \& Muin, J. A. (2018). Inclusive Education in Indonesia: Equality Education Access for Disabilities. KnE Social Sciences, 484-493. https://doi.org/10.18502/kss.v3i5.2351 